\title{
Does directors' experience positively moderate the impact of board busyness on firm efficiency? evidence from Asia-Pacific
}

\begin{abstract}
Purpose: The purpose of this paper is to examine the impact of board busyness on firm efficiency in the context of directors' experience, specifically on directors' experience that moderates the impact of board busyness on firm efficiency. Directors' experience is examined by exploring both depth (board tenure) and breadth (number of former listed directorship) of experience. Design/methodology/approach: This paper employs data envelopment analysis (DEA) to examine firm efficiency. Then, fixed effect panel regression analysis is applied to test the direct and moderating effect based on a sample of firms in the selected Asia-Pacific countries. Findings: Significant positive evidence for the moderating effect of directors' experience on the impact of board busyness on firm efficiency is documented. Practical implications: Findings are essential for managers, country policymakers and potential investors as inputs to improve the current company practices, laws and policies through the notion that directors' experience does enable the busy board to contribute to improved firm efficiency. Originality/value: This paper contributes to the debated perspectives on board busyness by providing initial evidence that directors' experience positively moderates the impact of board busyness on firm efficiency.
\end{abstract}

Keyword: Asia-Pacific; Firm efficiency; Board busyness; Directors' experience 
